\title{
Chapter 4 \\ Governance and Management Systems in Mediterranean Marine and Coastal Biosphere Reserves
}

\author{
Loredana T. Alfarè, Engelbert Ruoss and Amina Boumaour
}

\begin{abstract}
Recent studies in UNESCO World Heritage sites and Biosphere Reserves (BRs) identified gaps regarding the effectiveness of planning, governance, and management. The objective of a study carried out is to develop innovative approaches of evidence-based governance in UNESCO-designated marine protected areas in the Mediterranean Basin. Three different types of Biosphere Reserves have been selected for the present chapter: the Tuscan Islands Archipelago in Italy; the Terres de l'Ebre Delta in Spain; and the marine and coastal area of Gouraya in Algeria. Current and future evidence in the BRs differ and require actions related to the local realities and challenges. The Terres de l'Ebre BR is step by step implementing the new strategies and processes. The Tuscan Island BR has already prepared the frameworks and participatory instruments which await implementation. The Gouraya BR through the National Park established conservation and development functions, but for its realization it still seeks an increase of awareness and commitments of the authorities as well as management tools and funds. The "evidence-based governance and management system" is considered an integrated approach adequately involving the three dimensions top-down, bottom-up, and outside-in. It is an instrument to improve effectiveness of management and to involve the local communities and stakeholders in the decision processes in Biosphere Reserves.
\end{abstract}

Keywords Biosphere Reserves - Marine and coastal protected areas • Governance $\cdot$ Management $\cdot$ Planning $\cdot$ Participation • Evidence-based GMS • $\mathrm{UNESCO} / \mathrm{MaB}$ roadmap

L. T. Alfarè $(\bowtie)$

National Research Council—Institute of Marine Sciences, Venice, Italy

e-mail: loredana.alfare@ve.ismar.cnr.it

E. Ruoss

Università della Svizzera Italiana USI, Lugano, Switzerland

e-mail: engelbert.ruoss@usi.ch

\section{A. Boumaour}

National School of Marine Sciences and Coastal Management, Alger, Algeria

e-mail: boumaouramina@gmail.com 


\subsection{Introduction}

Protected area governance systems, whether state-run, private, or mixed, are dealing with "public goods" targeted to balance conservation and socioeconomic development. The governance models still show their roots in the traditional top-down approaches with governance and management systems (GMS) focused on coordination of conservation tasks without implementing integrated evidence-based approaches with inclusive participation and decision processes (Ruoss and Alfarè 2018, p. 263). The legal foundations or GMS is often insufficiently established and inefficient, and the political decision processes are lengthy and often delayed and do not respond to the increasing pressure (Eklund and Cabeza 2017). The main challenge of protected areas (PAs) today is to elaborate and share strategies improving efficiency and quality of governance, involving all relevant levels, public and stakeholders. Mobilizing the area's potential stimulates the local economy, knowledge development, and community interaction and achieves added value through generating innovation and contribute to smart, sustainable, and inclusive growth (Stoll-Kleemann et al. 2010; Ruoss 2013).

Recent studies (Ruoss 2017; Ruoss and Alfarè 2018) in UNESCO protected areas (PAs), World Heritage sites and Biosphere Reserves (BR), mainly in Europe identified gaps regarding the effectiveness of planning, governance, and management systems. In the EU Interreg project CHERPLAN (2011-2014), the planning and participation processes in heritage sites in South-Eastern Europe and the Alpine Space were studied, and solutions to overcome the gaps elaborated (ZRC SAZU 2014). To improve the balance between conservation and local development, recommendations have been elaborated, regarding the clarification of the strategic orientation, the holistic planning processes, the establishment of tools to measure the development, the involvement of local people and stakeholders in decision-making processes, and the fair sharing of benefits among all involved persons and institutions (Ruoss and Alfarè 2013).

The objective of the follow-up study is to develop innovative approaches of evidence-based governance in UNESCO-designated marine protected areas (MPAs). The study focuses on 20 Biosphere Reserves and 5 World Heritage sites, located within the Mediterranean Basin. This choice stems from the need to compare UNESCO protected areas that primarily concern natural and mixed sites and therefore have similar GMS systems. The selected sites are facing important challenges from the political point of view, especially those in North Africa. All of them are confronted with problems connected to climate change, pollution and marine litter, invasive alien species, financial constraints, pressure from tourism, and stakeholder involvement.

Multilateral environmental agreements (MEA) are agreements between states on specific environmental issues, and its implementation is delegated to the member states. UNESCO-designated sites follow such international frameworks and represent multilevel governance systems, from multilateral conventions and programs to 
local realities. In addition, they are requested to establish management systems and plans, which are suitable pre-conditions to introduce and test new approaches.

The investigations in the MPAs are aimed at understanding the governance and management systems, as well as identifying prospects to improve or transform them. The scope of this analysis is to assess similarities and differences as well as participatory processes in the GMS encountered in three case studies with different geographic areas, dimension, and diverse levels of local public and stakeholders' involvement in planning, decision making, and implementation. The results of the study should give new inputs to existing GMS and its state of implementation and in addition, indicate opportunities to improve the effectiveness of the systems facing new challenges and strategic frameworks.

\subsubsection{UNESCO Biosphere Reserves}

The "Man and the Biosphere" Program-MaB-is an intergovernmental scientific program, launched by UNESCO in 1970 and endorsed by its Member States in 1972. Its core mission is to balance the responsibility to protect nature and conserve biodiversity with the human need to use natural resources for enhancing social and economic well-being of peoples. The BRs are considered as "priority sites or observatories for biodiversity conservation as well as ecosystems and climate change research, monitoring, education, mitigation and adaptation" (UNESCO/MaB 2017, p. 53). The authority and accountability are assigned to the Member States, who implement the national legislation and eventually delegate the implementation at the regional and local levels. Therefore, traditional governance systems of the Biosphere Reserves as defined in the initial intergovernmental program were top-down GMS mainly connected to the national conservation legislation laid. The different governance levels share the responsibilities and provide funding and human resources for an effective conservation or protection of the PAs (Stoll-Kleemann et al. 2010).

With the New Roadmap for the MaB Program and its World Network of Biosphere Reserves, comprising the MaB Strategy (2015-2025), Lima Action Plan (2016-2025) and the Lima Declaration, a new dimension to the status of designated sites has been introduced (UNESCO/MaB 2017). The Lima Declaration asks the Member States to:

... develop and strengthen models of sustainable development; to communicate the experiences and lessons learned, facilitating the global diffusion and application of these models; to support evaluation and high-quality management, strategies and policies for sustainable development and planning, as well as accountable and resilient institutions ....

Accordingly, the Member States should establish effective governance and management structures and processes to the sustainable development functions. The Lima Action Plan explicitly aims at establishing "alliances at local, regional, international levels for biodiversity conservation and benefits to local people, taking into consideration the rights of indigenous people" (UNESCO/MaB 2017, p. 35, 52). Hence, the 
new MaB Strategy points to a changed paradigm of natural and cultural resources as substantial drivers of sustainable local development, creating added values and benefits for local people (Ruoss and Alfarè 2018).

\subsubsection{Participation in Evidence-Based Governance and Management Systems of Protected Areas}

In many countries, the delegation of authority and accountability to lower governance levels is progressing. More and more regional and municipal government bodies are in charge of site governance and management (Ruoss 2013, 2016). In some cases, the state government retains ownership and/or control and oversight of protected areas, but delegates the daily management tasks to a local governmental level or to a non-governmental organization, private operator, or community. State-governed sites often lack the legal obligation to inform or consult stakeholders or to involve them in decision making prior to establish PAs, meanwhile local bodies automatically consider bottom-up approaches in their decision and implementation processes.

A basic distinction among governance types can be based on who holds authority, responsibility, and accountability for key relevant decisions regarding a protected area. Accordingly, four main protected areas governance "types" were identified: government, shared or private governance, and local community governance (Jentoft et al. 2007; Borrini-Feyerabend 2013).

The evidence-based governance relates to local realities such as natural and cultural resources as well as local communities. Territories rich in diversity are characterized by varied social, economic, and physical features, and issues like ecological fragility, economic development challenges, and exposure to natural hazards are rarely reflected in mainstream datasets. PA policies need to build adaptive capacities by responding to local and regional specificities and by encouraging a diversity of strategies (Gløersen et al. 2016). An evidence-based and holistic governance depends on processes of deliberative democracy or deliberative decision making (Bessette 1980). Deliberative approaches adopt consensus decision making as well as majority regulations and therefore represent both representative and direct democracy.

The New Roadmap for the MaB Program asks for a holistic GMS approach based on the territorial evidences. The BRs should be "characterized by a wider and more active role of local communities in developing and deciding actions" at local level establishing new partnerships between scientists and decisionmakers, interlinking national and local governance, public and private sector actors, decision-making institutions, as well as citizens, in particular indigenous people (UNESCO/MaB 2017, p. 53). Also for the International Union for Conservation of Nature (IUCN), the participatory decision-making and planning processes are key to the success of Marine Protected Areas (MPA) management. "Local people must be deeply involved from the earliest possible stage in any MPA that is to succeed. This involvement 
should extend to them receiving clearly identifiable benefits from the MPA" (Kelleher 1999, p. xiii).

\subsubsection{Governance of Marine and Coastal Protected Areas}

The term marine protected area (MPA) applies to many types of marine parks and reserves including the coastal area with different levels of protection and a wide range of activities allowed or prohibited within their boundaries. Marine Protected Areas include a supplementary level of complexity and are therefore challenging regarding the establishment of effective governance and management systems. According to the European Commission, coastal areas face increasing impacts from human activities (e.g., shipping, transport, energy production, trade, fishing, port activities, tourism). When the carrying capacity is exceeding, due to the development of the coastal zone, marine and coastal ecosystems, this creates instability. Human activities are creating a decline of fish stocks; reduced water quality due to exceeding supply or insufficient waste water treatment capacity; sediment contamination from inland or marine pollution; and harming of coastal ecosystems especially coastal wetlands.

Coastal regions are also increasingly vulnerable to impacts of climate change, such as coastal flooding from rising sea levels; coastal erosion; water scarcity and droughts; saltwater infiltration of aquifers; habitat destruction; or loss of biodiversity. These negative environmental impacts usually lead to threats to key economic activities such as sustainable energy, tourism and trade, and social issues, including unemployment and social instability, loss of development, destruction of heritage and competition for resources. (EC 2012, p. 3)

The UN Convention on the Law of the Sea (UNCLOS 1982) is widely recognized as the overarching framework for marine governance. In most countries, coastal waters and their resources are considered "commons," which means not owned by any person or agency but are common property available equally to all citizens, with the government as "trustee." A primary aim of coastal conservation is to provide for sustainable use of the resources of the commons, a responsibility that should be shared by all people and all levels of government. As "trustee," the government is empowered to make rules for the commons that all must obey for the public good (Salm et al. 2000, p. 4).

The main differences of MPAs versus terrestrial PAs are the multi-dimensionality and connectivity, the "open systems, the currents and tides, the uncertainty and the higher complexity, as well as different property rights, enforcement and management" (Korting 2015). The Governance and Management Systems (GMS) of MPAs need therefore special attention since the "commons" are public goods with a high degree of delegation of authority and accountability to national governments and open for use to high numbers of stakeholders and people. Furthermore, the multiple interactions between the marine and the terrestrial part of the PAs request special attention regarding negative impacts and the need of targeted research and assessment of changes. 


\subsubsection{Maritime Spatial Planning}

Ecosystem-based approaches within the frameworks of Maritime Spatial Planning (MSP) and Integrated Coastal Zone Management (ICZM) ensure a sustainable use of the resources:

MSP is a key tool in articulating policies that balance conflicting sector-based interests
competing over the use of sea-space, a competition that is likely to intensify in the future.
Examples include the conflicts between traditional users (shipping, oil exploration, and
fishing) and emerging activities (tourism and recreational, aquaculture, or offshore renewable
energy), and between both types of users and marine protection, specifically in MPAs. (Blue
World Institute 2018)

MSP provides a process for a strategic and integrated plan-based approach to marine management that makes it possible to look at the "bigger picture" and to identify and manage current and potential conflicting uses, as well as the cumulative effects of human activities. It provides contextual information for the planning and management of MPAs. Processes become more transparent, and it provides greater certainty in planning and allocation processes for both developers and environmental managers (IUCN WCPA 2018). UNESCO's Intergovernmental Oceanographic Commission (IOC) and the Man and the Biosphere Program (MaB) have been working on moving MSP beyond the conceptual level. Several projects have been carried out applying MSP worldwide. In the Mediterranean area, the project ADRIPLAN focused on the Adriatic-Ionian Macroregion, zooming into two focus areas, one in the Northern Adriatic Sea and the other in Southern Adriatic (Adriplan 2015).

\subsubsection{Marine Protected Areas in the Mediterranean Basin}

The Mediterranean protected area Network (MedPAN 2018) listed 1231 MPAs and Other Effective area-based Conservation Measures (OECMs) in the Mediterranean covering $179,798 \mathrm{~km}^{2}$, which places a surface of $7.14 \%$ under a legal designation. For most sites, little is known about the management measures in place, and if they are effective at maintaining or restoring the biodiversity, they aim to protect (Ameer et al. 2008, p. 156). In the National Parks located in the Mediterranean Basin, four different governance types with different level of involvement of local people and actors have been described (Amine 2010):

- Centralized management by the state: Albania, Cyprus, and Morocco.

- Centralized management by the state with consultation of local actors and population: Algeria, Jordan, Montenegro, Turkey, and Tunisia.

- Management with participation of local actors in decision making: Croatia and Greece.

- Management with participation of local actors and consultation with local population: Spain, Italy, France, and Slovenia. 


\subsection{Methods}

The study carried out on 25 UNESCO designated MPAs has examined legislative and administrative documents at national/local level, management plans, projects, studies, scientific papers, Internet and gray literature. For each PA selected, a general description of the area (location, size, year of establishment, legal foundations, funding, zoning, governance and management systems, involved bodies, etc.) has been taken from existing sources. Regarding strategic governance and management issues, the updated data were missing (e.g., current number of staff, current budget, decision processes, updated strategies, and management plans). In 2018, missing information has been obtained through 13 interviews conducted by phone or e-mail with representatives of the PAs. The interviews were conducted in a semi-structured manner based on a trace aimed at investigating the actual management systems, the tools employed for engaging stakeholders, and the challenges faced by the BRs. The interviews were based on a standard question list so to allow a comparison between the different interviewers. For the present chapter, three different types of BRs have been selected: an archipelago "Tuscan Islands Biosphere Reserve" in Italy; a delta, the "Terres de l'Ebre Biosphere Reserve" in Spain, and a site with substantial marine and coastal zones "Gouraya Biosphere Reserve" in Algeria. The study sites permit a comparison of different legal foundations, governance systems, management of the sites, participatory processes as well as local realities.

\subsection{Results}

A preliminary analysis of all the 20 investigated BRs shows that the major part of the Mediterranean Biosphere Reserves overlap with other PA categories and have adopted the existing GMS of the respective National or Regional Parks. In the recent years, all Mediterranean countries with Biosphere Reserves have elaborated National Biodiversity Strategies and Sustainable Development Strategies. They are not yet implemented at PA level, and most sites still lack strategies, adapted management plans and funding to fulfill their supplementary tasks. It will take some time to translate them into concrete actions and adapt them to the Biosphere Reserve standards. The new strategies will help to further reduce impacts on cultural and natural heritage and fostering local development.

Different PA categories are frequently overlapping in such a way that the BRs are managed by National or Regional Park authorities and are based on PA management plans. Spain is the only Mediterranean country that through the Law 42/2007 on natural heritage and biodiversity integrates norms regarding protected areas established in international contexts such as UNESCO BRs (Spain 2007). The Italian Biosphere Reserves have no specific legal status, some of them partially or completely overlap protected areas recognized by national or regional laws. This corresponds to the Algerian BRs, which have a legal status as National Park. In this way, the develop- 
ment functions are still not or only partially introduced, and the GMS is following legislation for National and Regional Parks.

\subsubsection{Tuscan Islands Biosphere Reserve}

The boundaries of the Tuscan Islands Biosphere Reserve, defined in 2003 and extended in 2015, follow mostly those of the Tuscan Archipelago National Park established in 1996, with 79,160 ha the largest marine park in Europe (Fig. 4.1). The protection of its core areas is guaranteed by the National Park. The BR covers an area of 1,079,540 ha, composed of seven main islands, and is characterized by its high natural value, as well as by an intensive tourism activity, the most significant economic sector. The small dimensions of the various marine and terrestrial ecosystems also make the area extremely sensitive to climatic variations in the Mediterranean Basin. Therefore, it is an ideal place to observe and monitor the vulnerability in the face of climatic forcing (PNAT 2015).

The Tuscan Archipelago belongs administratively to the provinces of Livorno and Grosseto with a population of about 34,000 inhabitants, climbing up to 200,000 during summer. The recent increase of tourism has generated enormous pressure on the natural environment, for instance, on the Elba Island where there are 20,000 permanent residents which increases up to 200,000 people on a typical summer day (Casier 2011).

The main future challenges to be faced in the protected areas are related to climate change, especially sea level rise, sustainable tourism, fires and invasive alien species (IAS).

The Italian "Framework Law on Protected Natural Areas" no. 394/1991 (Italy 1991) outlines the fundamental principles for the establishment and management of protected areas regarding their mission, classification, and governance. It also defines the legislation for national and regional protected natural areas. The Law 426/1998 (Italy 1998) establishes the public-law personality of the park authority, legal and administrative offices in the territory and is subject to the supervision of the Ministry of Environment and Protection of the Land and Sea (MATTM). With regard to Regional Parks, the Law 394/1991 establishes fundamental principles through framework rules for the regions, attributing to local authorities' relevant roles and functions, such as the participation of Provinces, Mountain Communities, and Municipalities to the procedures for the establishment of protected areas.

The park bodies are: the President, the Governing Council, the Executive Committee, the Board of Auditors, and the Park Community. The President is the legal representative of the entity for five years and is appointed by decree by the Minister in charge of environment, in agreement with the President of the Tuscany region. The Governing Council and its President decide on all general matters and the budget. Its Executive Committee makes proposals to the Governing Council. The Director is responsible for the management of the park and consequently for the BR. The 


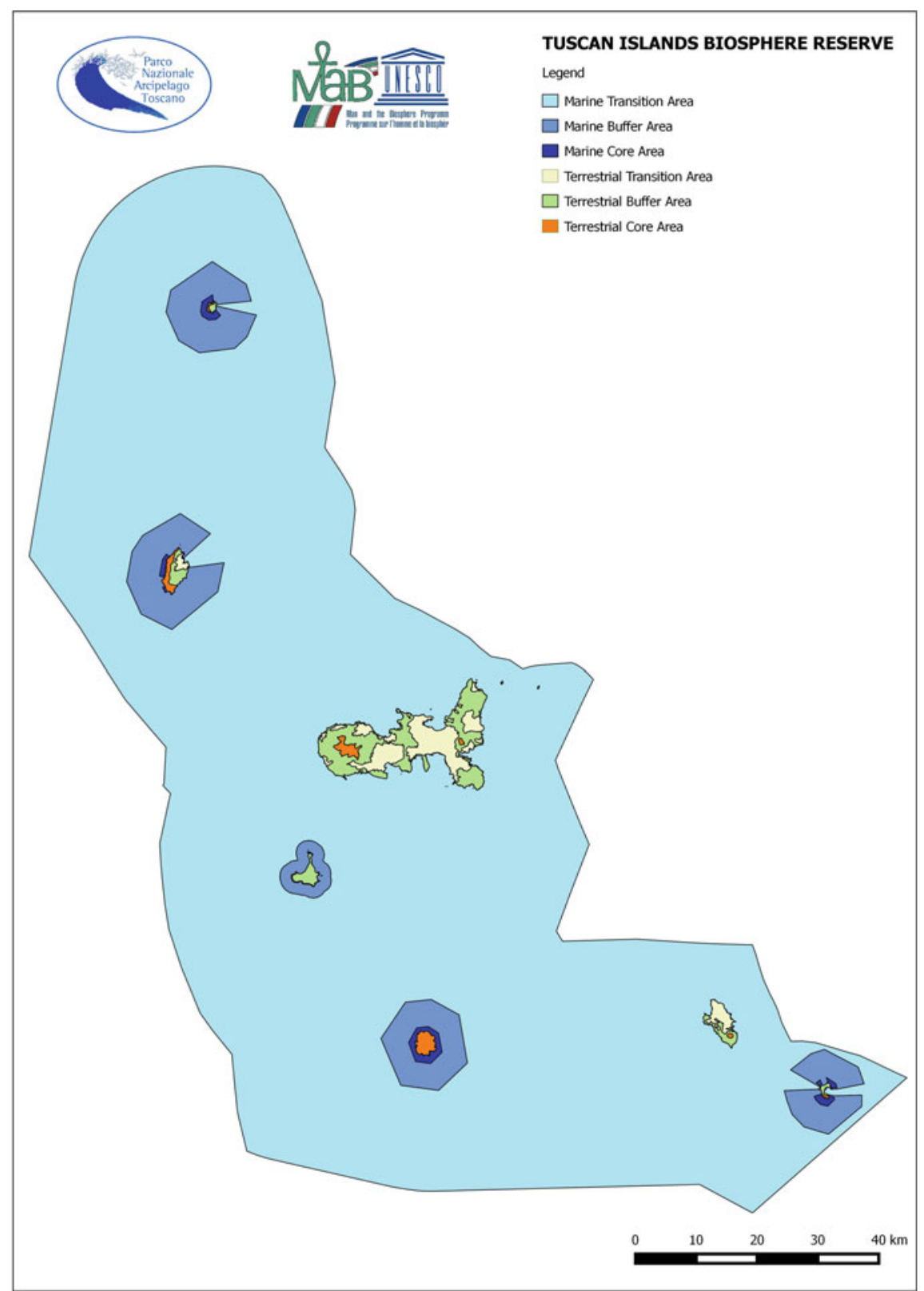

Fig. 4.1 Zonation of the marine and terrestrial zones of the Tuscan Islands Biosphere Reserve (Source PNAT 2015) 
Board of Auditors has the task to control the administrative and accounting of the institution.

The Park Community is an advisory body constituting the interface with the local communities and includes the President of the Tuscan region, the chairmen of the provinces of Livorno and Grosseto and the mayors of the 11 municipalities of the park. It articulates its opinion on the fundamental acts of the park plan, the regulations, and the budgets. The participation process is required by the mentioned Framework Law and is ensured by the Park Community, but there are no legal provisions for direct citizen involvement because the members of the Park Community are representatives of the local bodies and not citizens. A study of the Italian legal framework shows that it is very specific and rigid regarding who can legally participate (Buono et al. 2012).

The park plan was issued in 2009 with a long process of analysis and comparison, and enhancing the involvement of local communities. The final documentation was sent to the authorities with environmental competences and made available for 80 days for public consultation. According to the "Plan of Performance," issued every three years, the participation process has been accelerated in the last years through meetings with the representatives of various economic sectors. Operational inputs have been received also from educational institutions, volunteers, public and private institutions. According to the Sustainability Report of the Park (PNAT 2017), protocols have been endorsed with several institutions for the implementation of the planning strategies. The involvement of local actors in evaluating the effects produced by the park's activities, the engagement of municipal, provincial, and regional councils with the necessary elements of knowledge to set up and verify the policies of protection and development of the territory and a structured dialogue with economic operators for co-design of itineraries and tourist packages are examples of the participatory process applied by the park. Thanks to the participation to EU projects (e.g., Life Montecristo, Resto con Life, Life ASAP) a real involvement of citizens has been promoted through workshops and working groups.

The BR budget is part of the park budget, which is financed mainly by the MATTM. In 2015, the park budget was 4.9 million Euros (state $94 \%$, region and other public bodies $0.19 \%$, own revenue $4.6 \%$, and other funds $1.2 \%$ ) (PNAT 2017).

A management plan for the BR was elaborated in 2015, but it has not yet been approved. According to this document, the GMS will include: (i) Coordinator (President of the park), (ii) Management Committee composed by representatives of research institutions, associations, and other authorities; (iii) MaB Office composed by personnel of the park and professionals, organizing the MaB participatory workshops aimed at enhancing the participation of local communities in the BR management; (iv) Permanent Consultative Assembly composed by the President of the Park, the representatives of the 11 municipalities, the State Forestry Corps and Port authorities which has to ensure the participation and involvement of local authorities, and approve and monitor the effectiveness of the program management. 


\subsubsection{Terres de l'Ebre Biosphere Reserve}

The Terres de l'Ebre Biosphere Reserve (RdBTE) endorsed in 2013 covers an area of 367,729 ha and has a population of 182,521 inhabitants, distributed in 45 municipalities. The BR is located in North-Eastern Spain and encompasses the three counties (comarques) - Baix Ebre, Montsià, and Terra Alta. The RdBTE includes a wide range of ecosystems with outstanding biodiversity. Its landscapes are heterogeneous, due to the geomorphology and human activities. The evolution of the Delta del Ebro is an exceptional example of the ongoing natural landscape and human dynamics. The diverse mosaic of ecological systems existing in the lands of the Ebro is represented by the four sectors of the core of the Biosphere Reserve (RERB 2013) : the Delta, Els Ports massif, the Sierra de Cardó, and the maritime centers (Fig. 4.2).

The national law 33/2015 revises and amends the Law 42/2007 (Spain 2015, 2007), improving certain aspects of its applicability such as the management of environmentally protected areas, the incorporation into the Spanish legal system of obligations derived from EU legislation and international protocols recently ratified by Spain. It also aims to allocate competences between the central and the regional governments in marine environment-related matters. At state level, the Ministry of Agriculture, Food and Environment is the main regulatory body. The local autonomous regions (Comunida des Autónomas) develop and enforce their own environmental legislation, and local authorities have as well environmental protection powers. Accordingly, enforcement of environmental law is carried out at state, regional, and local authority levels (Lavilla et al. 2016).

The regional government (Generalitat de Cataluña) is the responsible body that has delegated to COPATE (Consorzi de Politiques Ambientals a les Terres de l'EbreTerres de 1'Ebre Environmental Policies Consortium) for the RdBTE's management. The Executive Committee is the decision body, which has its own and exclusive regulation within COPATE and has the function of developing, evaluating, and establishing mechanisms to execute the decisions in the territory of the BR. The organization system foresees the support of an Advisory Council providing guidelines for the designing of territorial development policies and coordinates the thematic working groups and the Socio-Environmental Observatory that is responsible for monitoring the implementation of the management plan. The Brand Appraiser Committee is responsible for drafting the regulations connected to the use of the brand "Terres de l'Ebre Reserva de la Biosfera." The average annual budget is around 100,000 €. Funding is provided mostly by EU projects (50\%), region (20\%), and own funds $(30 \%)$.

The RdBTE has fostered a continuing debate and coordination with the local and territorial administrations, competent with the social and economic agents of the area; exerting, if necessary, the role of mediator and moderator of various interests, sectors, and visions existing in the lands of the Ebro in order to help articulate a common project of the territory the broadest possible (COPATE 2017a).

The BR has always involved the citizens in the discussion and the management of the territory, establishing a participatory governance model, setting up meeting 


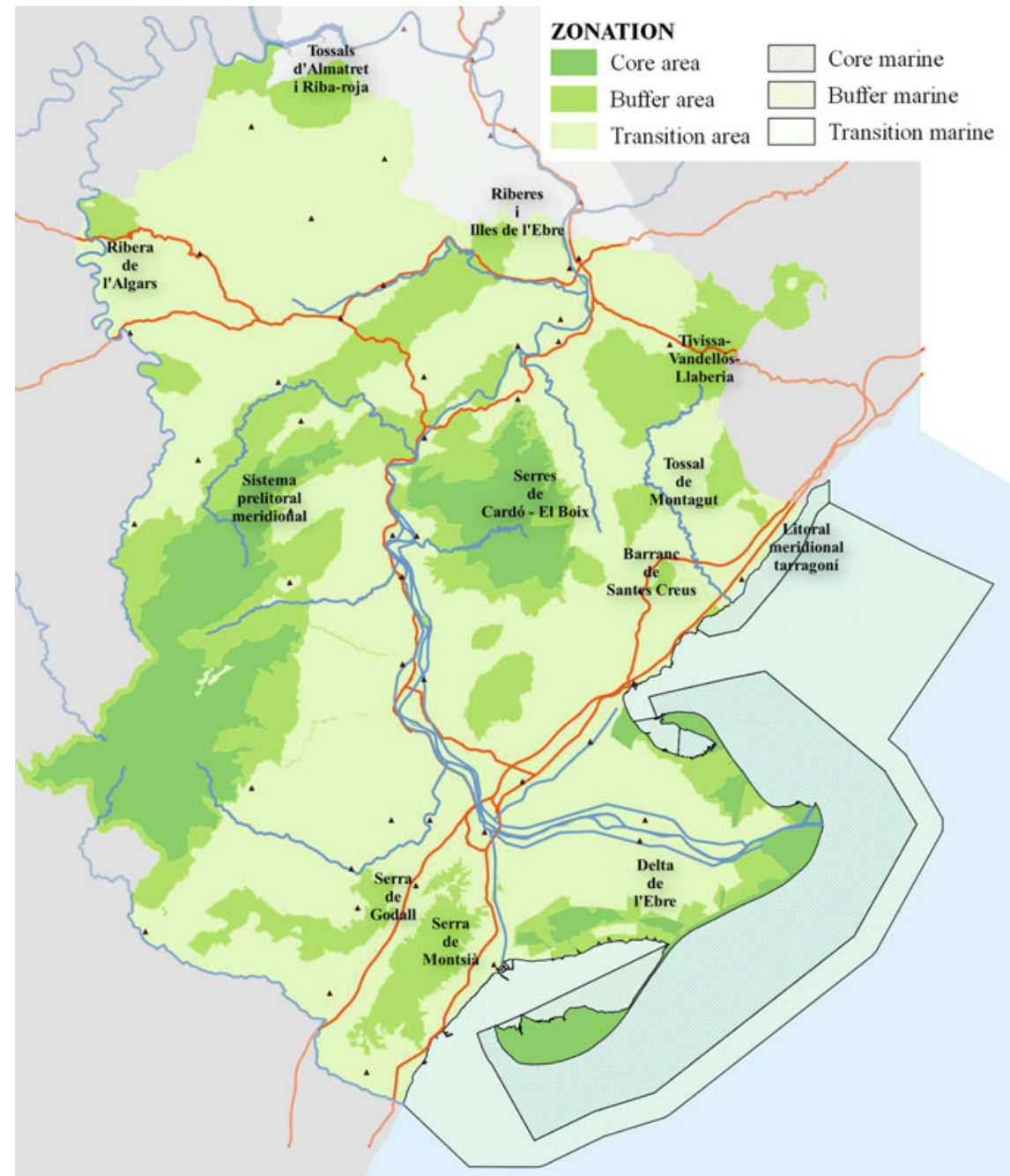

Fig. 4.2 Localization and zonation of the Terres de l'Ebre Biosphere Reserve (Source COPATE 2017b, adapted by COPATE in 2019)

spaces that encourage the critical debate and the strategic consensus of the different territorial actors. The RdBTE promotes a proactive participation of the main players and of society in general, through the establishment of thematic working groups or commissions (permanent or temporary). Their constitution and operation are tailored to the suitable needs at the moment and the addressed goals. In this way, it will create spaces or points of regular meetings for the exchange of information, to generate knowledge, evaluate strategies and objectives. The actions related to the management plan and participatory process are addressed in several projects funded by the EU 
(e.g., Life Ebro-Admiclim, Life Clinomics, Destimed) providing concrete solutions and a real benefit for the fragile ecosystem of the area and for the community.

The RdBTE is facing difficult challenges connected to loss of wetlands and rice fields due to coastal regression caused by lack of input of fluvial sediments, regression of the coast ( $10 \mathrm{~m}$ per year at the river mouth), reduction of the average elevation of the Delta due to sea level rise and subsidence. All these aspects have been taken into consideration in the management plan as well as the impacts of climate change and invasive alien species invasion (COPATE 2017b: MP Line of action 2.5.2 and 1.2.3). The actions foreseen include climate change adaptation and mitigation measures, multi-functionality of agriculture, promotion of the green and circular economy, promotion of research, innovation, transfer of knowledge, improvement of the communication, dissemination and education.

\subsubsection{Gouraya Biosphere Reserve}

The National Park of Gouraya (NPG) was created in 1984 and has been classified as a Biosphere Reserve since 2004. It is located east of Algiers in the heart of the Wilaya (Province) of Bejaïa.

The site, considered the smallest in term of surface at the national level, is composed of three areas: a terrestrial one with an area of 2080 ha including a coast of $11.5 \mathrm{~km}$, the lacustrine of $2.5 \mathrm{ha}$, and the planned extension of a marine area of 7842 ha (Fig. 4.3). The BR is characterized by a considerable geomorphological and ecological diversity within a very confined space. It is a "hot spot" and one of the high-endemic areas of the Mediterranean Basin with high heritage value species threatened or endangered. The site has also a cultural value owing to the presence of numerous historic sites among which several are classified (GFD 2006).

The unique location of the Gouraya BR makes it subject to intense human pressures caused by its proximity to the city of Bejaïa, which represents only $3.72 \%$ of the total area of the Wilaya with about $21 \%$ of total population of the latter $(\sim 187.000$ inhabitants) (DPSB 2015). Added to that, the vicinity of the harbor complex (ranked first in the country), as well as the important socioeconomic development, the industrial area of Bejaiia being classified among the most important industrial clusters of the country.

The BR encompasses 12 villages, home to nearly 2000 inhabitants. The location of the site upstream of Bejaïa city has conferred it an urban character. Consequently, the presence of local visitors and tourists (exceeding annually 500,000 arrivals) in the protected area increased especially during the weekends and the summer season (DPSB 2015). The advantage of this location in terms of management is that the park managers have only the Wilaya and the Municipality of Bejaiia as interlocutors.

In order to protect the environment from the pressures undergone, a legislative framework was established; i.e., Law $\mathrm{n}^{\circ} 02-02$ on the protection and the promotion of the coastline and Law $\mathrm{n}^{\circ} 03-10$ on the protection of the environment in a context of sustainable development (Algeria 2002, 2003). Furthermore, the National Commis- 


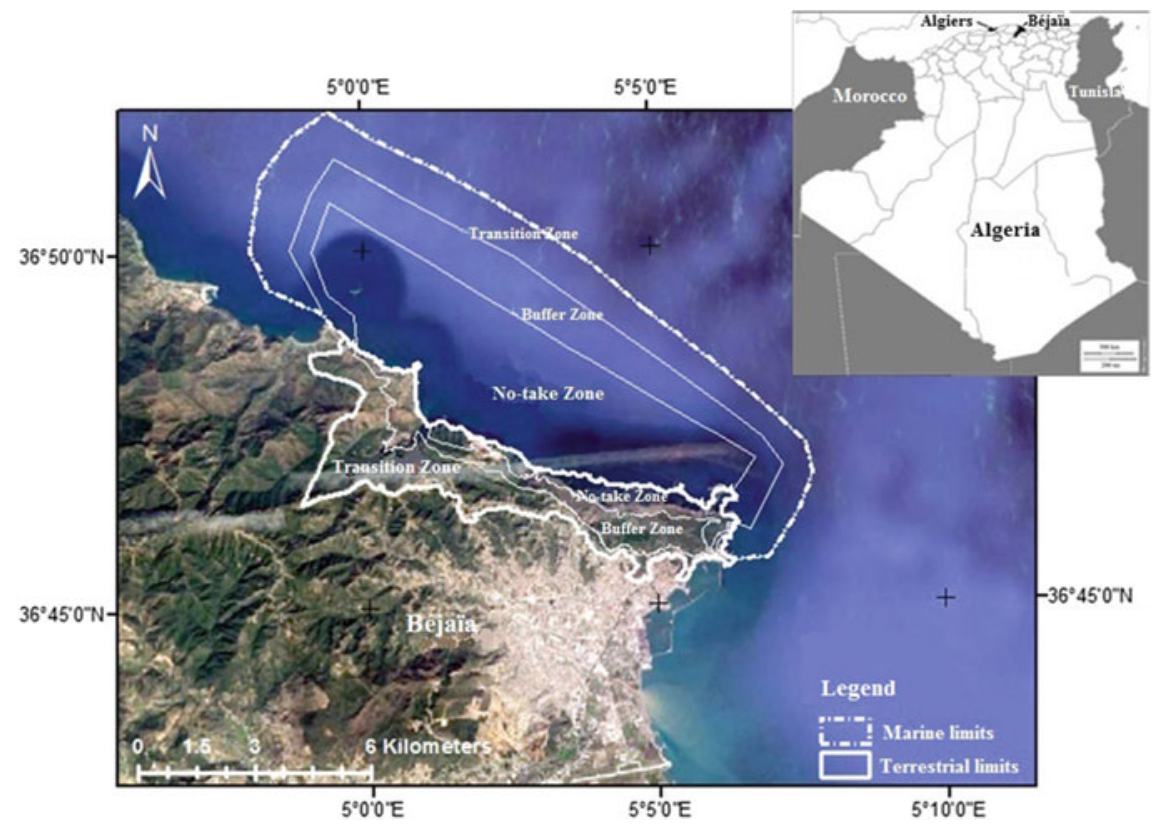

Fig. 4.3 Localization and zonation of the Gouraya Biosphere Reserve and the planned extension of marine zones

sion of the Littoral was created in 2004 to ensure the implementation of the national policy for the protection and development of the coastline and the coastal zone. Protected areas in Algeria are created and managed by the Ministries of Environment and Agriculture (Forests Directorate). The Law ${ }^{\circ} 11-02$ on protected areas in the context of sustainable development has provided dispositions for the successful process of classification and management of protected areas (Algeria 2011). These areas are entrusted to a public administrative institution including a Scientific Council and a Guidance Council. This latter is composed of representatives of different ministries, local elected representatives, scientists, and an environmental protection association. It is responsible for deliberating on the development and implementation of the park management plan, and the activities carried out in matters related to the missions, organization, and operation of the National Parks.

Today, the BR is founded on the national legislation of protected areas and managed by the National Park, according its fourth Management Plan adopted in 2015. It determined, as main orientations and objectives, the protection of biodiversity, the capacity building and the collaboration with scientific researchers and associations for knowledge acquisition, the awareness rising, as well as the development of sustainable activities.

The park was created without consulting the local community and provoked consequently a strong opposition. The managers, therefore, had to deploy tremendous efforts to integrate the population through communication and awareness rising and 
by visiting even at home to explain the missions and objectives of the park, as well as through eco-development actions.

Some actors are directly involved in the BR management through the Guidance and Scientific Councils. They are considered as platforms for the integration and the participation of stakeholders. Decisionmakers participate in the management through awareness raising, protection, and conservation activities, as well as conducting studies and implementing projects. Scientists implement research programs, and the associations are involved in different projects as they organize voluntary actions and visits to raise awareness among citizens; they are also invited by managers and other partners to participate in the celebration of various national and international events. The involvement of the local population is mainly achieved through eco-development actions for the benefit of the inhabitants of the park (Boumaour et al. 2018).

The project of the marine area classification was initiated by the managers of the park in the early 2000s and a participatory process involving the users of the future MPA has been launched, aimed at ensuring the support of all stakeholders to the project. A steering committee was set up including the representatives of the different sectors, local authorities, fishermen associations, and scientists.

A project launched in 2014 in cooperation with the MedPAN (2016) enabled the creation of a participation platform involving various stakeholders: fishermen's organizations (small-scale and industrial), environmental NGOs, diving clubs, scientists, and local authorities. This led to the co-construction and adoption by the actors of the charter of good practices for a sustainable fishing in the Gouraya MPA. The project has allowed to change the perceptions of some participants toward the MPA, particularly the small-scale fishermen associations that defended the MPA project and sensitized the audience to its importance. This reflects their awareness of the stakes and their ownership of the project.

\subsection{Discussion}

\subsubsection{Comparison of Participation in Governance and Management in Selected Biosphere Reserves in the Mediterranean Area}

Terres de l'Ebre BR is the only site with proper institutional and organizational identity. Its governance and management is delegated to COPATE, including regional and local authorities, which also provides funding, guidance, and monitoring. Its participatory governance model is based on a continuous and proactive involvement of local population and stakeholders in decision making and implementation of actions regarding the priorities defined in the Management Plan. Thematic working groups and permanent or temporary commissions are constituted, and their operation tailored to the previously defined goals and needs. Points of regular meetings for the 
exchange of information, to generate knowledge, evaluate strategies and objectives are established to guarantee the open debate in all the phases. In a series of projects, they are dealing with the promotion of the BR brand as well as future challenges, e.g., impacts of climate change, alien species invasion or threats to local agriculture.

The Tuscan Island BR and the Gouraya BR are following the legislation established for the National Parks and do not have yet implemented specific BR Governance and Management Systems. Due to their legal status, their decision processes are still top-down, and the budget is generated mainly through contributions by the state authorities (Table 4.1).

The Tuscan Island BR realized a considerable enlargement in 2015 as well as a draft Management Plan. Hence, the Governance and Management System and its bodies, status, mandate, and participatory processes defined for the National Park are still in place. The new BR strategies for conservation and sustainable development as well as an overarching BR governance and management system, responsible for the core, transition, and development zones, including the vast marine area are not yet approved. The Tuscan Island BR will be a pioneer for a new generation of Marine and Coastal BRs, extending the limits beyond territorial waters to adequately guarantee all the future objectives of the Reserve (e.g., the Sanctuary for Mediterranean Marine Mammals).

Consequently, the delegation of authority and accountability will have to be redefined. The participation of the public in planning, decision making, and implementation of the targets, especially in the marine part of the BR, will ask for new deliberative democratic models.

\footnotetext{
In the past, the sea was considered an essentially free space by Italian regulations, as an inexhaustible natural resource available to everyone. Therefore, the general consensus was that the sea cannot be considered as a "good" in the true sense of the term and was not open to becoming the object of property rights, be them private or public. It was subject only to individual freedoms, and the police powers of the state. In recent times, the possibility for economic and industrial exploitation of the sea and the increased variety in its potential uses, together with the increasing need to protect it against pollution and manage its relative resources, now mean that this traditional attitude toward its use is undergoing revision .... The sea, according to recent interpretations, is now being considered a good that needs to be subject to land management policies and entrusted to authorities with administrative functions. (Management Plan 2015 Appendix 1).
}

The Gouraya National Park has already adopted the BR concept and established its functions. The bottom-up processes in decision making are not yet established, and the share of duties and benefits with local communities and stakeholders is not defined. Since communication and conflict resolution had been a major challenge of the park management at the beginning, it introduced in practice an enhanced delegation of duties at the local level and the involvement of local stakeholders. The stakeholder participation in the decision-making process was established with the creation of the Guidance Council and Scientific Council in 2013 and 2014, respectively. Pressure from increasing urbanization, resource use and tourism reveal the limits of the park authorities, which lack personnel, infrastructure, and delegated authority regarding the development functions of the BR. The National Strategies 
4 Governance and Management Systems in Mediterranean ...

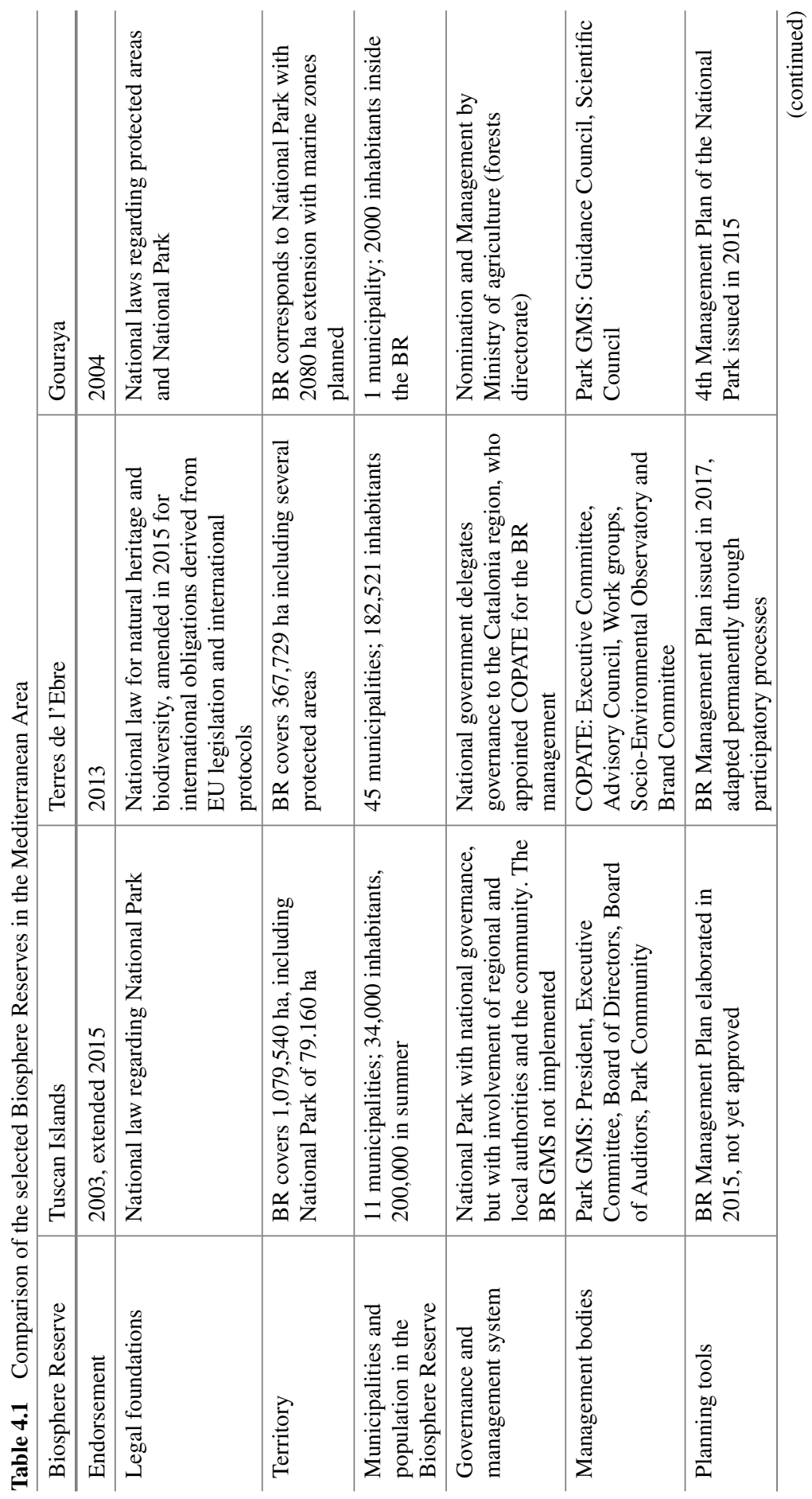




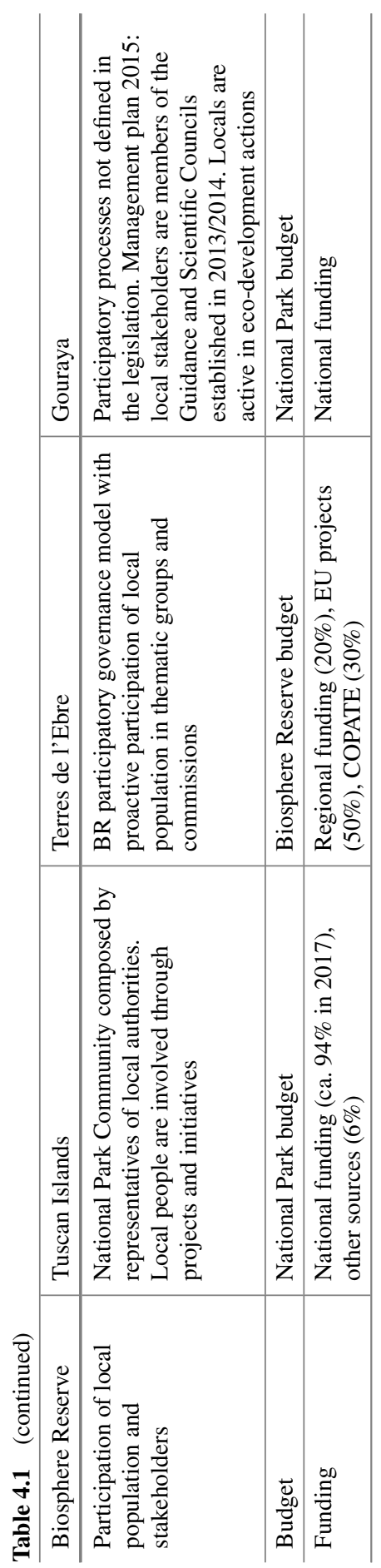


and Action Plans for the Environment and Sustainable Development (2002) and the Biodiversity (2016) are coherent with the new BR Roadmap (UNESCO/MAB 2017, para 23 , p. 54), but are slowly being translated in the local context mainly due to reduced budgets. They should be better reflected in the future Management Plans of the National Park and BR. The state of the art of the Gouraya BR mirrors well the general situation of the Maghreb countries. During the IUCN-Atelier Régional sur: "La Gouvernance des Réserves de Biosphère au Maghreb: état et perspectives" in Tanger, Maroc (IUCN 2012), the PA managers discussed the problems and challenges of the North African sites. The participants concluded that the main problems of PAs relate to inappropriate legal frameworks and the lack of management structures dedicated to BRs like coordination, awareness, and communication programs, with little participation of the population. BR Management Plans and budget include insufficient public funds, which are mainly foreseen for the protected areas.

\subsubsection{Integrated GMS Approaches Related to Protected Areas}

The exceptional assets and high community-development potential of UNESCO sites requires innovative deliberative "evidence-based governance" which are transborder, multilevel, pluralistic, dynamic, respecting ecological and social limits, adaptive and open to changing constraints. Integrated governance and management approaches of protected areas should aim at knowledge-based development involving local society, adapted to available resources and area's social, cultural, and environmental specificities. Regarding MPAs, IUCN has concluded (IUCN 2018, p. 2):

Building effective partnerships between the management authority and communities remains a major challenge. It is of the utmost importance that communities be motivated toward active involvement in all stages of MPA planning and operation. During the last two decades, the number of communities effectively participating in MPA affairs through collaborative management (or co-management), approaches has increased greatly.

Innovative governance and management frameworks and methodologies such as the Outcome-Oriented Public Management (Schedler and Proeller 2010), the SocialEcological Systems (SES) (McGinnis and Ostrom 2014), SDI method (Ruoss 2007), NEXUS methodology or the Sustainability Profile Matrix (Gløersen et al. 2016), have paved the way to adopt new integrated territorial governance and management approaches in Biosphere Reserves and areas with focus on rich natural and cultural heritage.

The "evidence-based GMS" (Ruoss and Alfarè 2018) is an integrated approach characterized by the adequate involvement of the three dimensions: top-down, bottom-up, and outside-in. International and national bodies define the overarching standards, norms and legal frameworks and financial contributions, and delegate authority and accountability to the local, operative level. Bottom-up processes define strategies and objectives based on local place-based evidences such as resources, needs, and challenges. The local population will, as defined in the new BR Roadmap 
(UNESCO/MaB 2017), not only actively participate, they will also profit from benefit and added values as a return of their investments and partnership. Public and private institutions have a key role in the outside-in processes, providing knowledge, funding, networking, and facilitate research, innovation, and communication.

\subsection{Conclusions}

The selected case studies are representative for the Mediterranean BRs; they have sound strategic frameworks in place and are advancing in the transformation of their past and present to the new paradigms. The considerable challenges expected in the near future will harm especially the coastal area and the local economy. The target of protecting the natural and cultural resources and the endangered ecosystems require adequate instruments to adapt to the potential impacts. Commitment of the authorities, clear purpose and priorities, coordination of the transformation processes, awareness of the vulnerable natural and socioeconomic equilibrium as well as open and transparent communication will be needed on the way forward.

The present and future evidences in the three selected BRs are completely different and require solutions, which correspond to the local realities and obstacles. The Terres de l'Ebre BR is implementing step by step the new strategies and processes. The Tuscan Island BR has already prepared the frameworks and participative instruments that await implementation. The Gouraya BR has already established conservation and development functions through the National Park but still needs an increase of awareness and commitments of the authorities as well as the tools and funds to fully define and implement the new BR strategy.

The evidence-based GMS with a holistic three-dimensional approach could be a way forward to improve or establish effective tools and to involve the local communities, especially the multiple stakeholders, in the decision processes. It will not be enough to delegate authority and accountability to the local level. People and stakeholders have to develop an ownership for the future conservation and development of the sites and will need knowledge, information, funding as well as decision and monitoring tools to act accordingly.

\section{References}

Adriplan (2015) Adriatic Ionian maritime spatial planning. www.adriplan.eu. Accessed 23 Jul 2018 Algeria (2002) Loi relative à la protection et à la valorisation du littoral (Law on the protection and the promotion of the coastline) no. 02-02 du 5 Février 2002. Journal Officiel de la Republique Algérienne no. 10 du 12 Février 2002, p 18 https://www.joradp.dz/HFR/Index.htm. Accessed 23 Jul 2018

Algeria (2003) Loi relative à la protection de l'environnement dans le cadre du développement durable (Law on the protection of the environment in the context of sustainable development) no. 
03-10 du 19 juillet 2003. Journal Officiel de la Republique Algérienne no. 43 du 20 Juillet 2003, p 6

Algeria (2011) Loi relative aux aires protégées dans le cadre du développement durable (Law on protected areas in the context of sustainable development) no. 11-02 du 17 Février 2011. Journal Officiel de la Republique Algérienne no. 13 du 28 Février 2011, p 8

Ameer A, Gomei M, Maison E, Piante C (2008) Statut des Aires Marines Protégées en Mer Méditerranée. UICN, Malaga et WWF, France

Amine K (2010) Les parcs nationaux de la Méditerranée. In: Les Actes du Colloque"Les parcs naturels e l'Union pour le Méditerranée" La Garde, 10-11 Juin 2010. Annexe 1

Bessette JM (1980) Deliberative democracy: the majority principle in republican government. In: How democratic is the constitution? American Enterprise Institute for Public Policy Research, Washington [u.a.], pp 102-116

Blue World Institute (2018) Adriatic + https://www.blue-world.org/what-we-do/our-projects/ adriatic/. Accessed 23 Jul 2018

Borrini-Feyerabend G, Dudley N, Jaeger T et al (2013) Governance of Protected Areas: From understanding to action. Best Practice Protected Area Guidelines Series no. 20, IUCN, Gland, Switzerland: xvi + p 124

Boumaour A, Grimes S, Brigand L, Larid M (2018) Integration process and stakeholders' interactions analysis around a protection project: case of the national park of Gouraya, Algeria (Southwestern Mediterranean). Ocean Coast Manag 153:215-230. https://doi.org/10.1016/j.ocecoaman. 2017.12.031

Buono F, Carsjens GJ, Pediaditi K (2012) Local community participation in italian national parks management: theory versus practice. J Environ Planning Policy Manage 14(2):1-20. https://doi. org/10.1080/1523908X.2012.683937

Casier R (2011) Marine protected areas in the mediterranean sea. Alfred Toepfer Foundation, EUROPARC Federation, Regensburg, Germany

COPATE (2017a) Estratègia en l'àmbit socioeconomic i pla de gestiò 2015-2023 de la Reserva di Biosfera Terres de l'Ebre. http://www.ebrebiosfera.org/docs/PLA_GESTIO_2017_RdBTE.pdf. Accessed Aug 2018

COPATE (2017b) Management plan of the terres de l'Ebre biosphere reserve. Draft Report Sep 2015. http://www.copate.cat/sections/reserva-de-la-biosfera-terres-ebre/pla-accio.aspx. Accessed Jul 2018

DPSB (2015) Statistical yearbook of Bejaïa 2015. The Directorate of Budgetary, Programming and Monitoring of the Wilaya of Bejaïa

EC (2012) LIFE and coastal management. European Commission, Brussels. https://doi.org/10.2779/ 54470

Eklund J, Cabeza M (2017) Quality of governance and effectiveness of protected areas: crucial concepts for conservation planning Ann. N.Y. Acad. Sci. 1399:27-41. https://doi.org/10.1111/ nyas. 13284

GFD (2006) Atlas des Parcs Nationaux algériens. Direction Générale des Forêts. https://docplayer. fr/22809409-Atlas-des-parcs-nationaux-algeriens.html. Accessed Aug 2018

Gløersen E, Mader C, Ruoss E (2016) What policy evidence for a European strategy of sustainable development in mountain regions? Revue de Géographie Alpine 104(3):1-20

Italy (1991) Legge quadro sulle aree protette (Framework law on protected areas). Law no. 394/1991 of 6 December 1991. Gazzetta Ufficiale n. 292 of 13 December 1991

Italy (1998) Nuovi interventi in campo ambientale (New interventions in the environmental field). Law no. 426/1998 of 9 December. Gazzetta Ufficiale n. 291 of 14 December 1998

IUCN (2012) Atelier Régional sur: "La Gouvernance des Réserves de Biosphère au Maghreb: état et perspectives" Tanger, Maroc: 5-8 Mars 2012

IUCN WCPA (2018) Applying IUCN's global conservation standards to marine protected areas (MPA). Delivering effective conservation action through MPAs, to secure ocean health \& sustainable development. Version 1.0. Gland, Switzerland 
Jentoft S, van Son TC, Bjørkan M (2007) Marine protected areas: a governance system analysis. Human Ecology 35(5):611-622. https://doi.org/10.1007/s10745-007-9125-6

Kelleher G (1999) Guidelines for marine protected areas. IUCN, Gland, Switzerland and Cambridge, UK. xxiv + p 107

Korting J (2015) Challenges for marine protected areas-and examples for addressing them. Blue Solutions, Vilm Seminar "Biodiversity Conservation for Human Wellbeing" 4 August 2015. https://www.iucn.org/sites/dev/files/import/downloads/150819_mpa_challenges_ vilm_rev_1.pdf. Accessed 21 Jul 2018

Lavilla JJ, Barrios JM, Ramos I, Canseco O, Clifford Chance SL (2016): Environmental law and practice in Spain: overview. Law stated as at 01-Oct-2016. https://uk.practicallaw.thomsonreuters. com/0-521-6274?transitionType=Default\&contextData $=(\mathrm{sc}$. Default $) \&$ firstPage $=$ true $\&$ comp $=$ pluk\&bhcp $=1$. Accessed 4 Nov 2018

McGinnis MD, Ostrom E (2014) Social-ecological system framework: initial changes and continuing challenges. Ecology and Society 19(2):30. http://dx.doi.org/10.5751/ES-06387-190230. Accessed 21 Jul 2018

MedPAN (2016) Leaflet on the projects financed between 2014 and 2016. https://drive.google.com/ file/d/0Bw8D-TFFFccxYjRwVnB6eXIXZ3c/view. Accessed 15 Mar 2019

MedPAN (2018) Network of marine protected areas managers in the mediterranean. http://medpan. org/marine-protected-areas/mediterranean-mpas/. Accessed 23 Jul 2018

PNAT (2015) Parco Nazionale Arcipelago Toscano. Management Plan for the Tuscan Islands Biosphere Reserve (draft document)

PNAT (2017) Parco Nazionale Arcipelago Toscano-Bilancio di Sostenibilità 2015-2016. http:// www.islepark.it/ente-parco/bilancio-di-sostenibilità. Accessed 23 Jul 2018

RERB (2013) Map of the Terres de L'Ebre Biosphere Reserve. Red Española de Reservas de Biosfera (RERB). http://rerb.oapn.es/red-espanola-de-reservas-de-la-biosfera/reservas-de-labiosfera-espanolas/mapa/terres-de-lebre/ficha. Accessed 4 Nov 2018

Ruoss E (2007) Methodological Manual-RFO INNOREF: Innovation and Resource Efficiency as Driving Forces for Sustainable Growth - EU INTERREG IIIC East programme 2004-2007. Final Project Report, p 30

Ruoss E (2013) Biosphere Reserves as Model Sites for Sustainable Development. In Getzner M, Jungmeier M (eds) Protected areas in focus: analysis and evaluation. Proceedings in the management of protected areas, vol 4:99-114

Ruoss E (2016) Opportunities to leverage World Heritage Sites for local development in the Alps. eco.mont 8/1:53-61. https://doi.org/10.1553/eco.mont-8-1s53

Ruoss E (2017) Welterbe und Biosphärenreservate. Lernen von Modellen einer dynamischen Regionsentwicklung. Proceedings of the Tourism Forum Salzburg 2016:235-259

Ruoss E, Alfarè L (eds) (2013) Sustainable Tourism as Driving Force for Cultural Heritage Sites Development. Planning, Managing and Monitoring Cultural Heritage Sites in South East Europe. CHERPLAN Report. http://www.cherplan.eu/sites/default/files/public_files/ Sustainable\%20tourism\%20in\%20SEE.pdf. Accessed 21 Jul 2018

Ruoss E, Alfarè LT (2018) Shifting protected area strategies to evidence based governance and management. Conference Volume of the 6th Symposium For Research in Protected Areas, 2-3 November 2017, Salzburg, pp 561-564 https://epub.oeaw.ac.at/symposium_on_protected_area. Accessed 21 Jul 2018

Salm RV, Clark J, Siirila E (2000) Marine and Coastal Protected Areas: A guide for planners and managers. IUCN. Washington DC. xxi $+371 \mathrm{p}$

Schedler K, Proeller I (2010) Outcome Oriented Public Management. A Responsibility-Based Approach to the New Public Management. Information Age Publishing, Inc. Charlotte, North Carolina

Spain (2007) Ley del Patrimonio Natural y de la Biodiversidad (Law on Natural Heritage and Biodiversity) Law no. 42/2007 of 13 December 2007. BOE n. 299 of 14 December 2007 
Spain (2015) Ley, por la que se modifica la Ley 42/2007, de 13 de diciembre, del Patrimonio Natural y de la Biodiversidad (Law on Natural Heritage and Biodiversity revising the Law 42/2007) Law no 33/2015, of 21 September 2007. BOE n. 227 of 22 of September 2015

Stoll-Kleemann S, de la Vega-Leinert AC, Schultz L (2010) The role of community participation in the effectiveness of UNESCO Biosphere Reserve management: Evidence and reflections from two parallel global surveys. Environ Conserv 37(3):227-238. https://doi.org/10.1017/ S037689291000038X

UNCLOS (1982) United Nations Convention on the Law of the Sea of 10 December 1982. Last updated 28 March 2018. http://www.un.org/depts/los/convention_agreements/convention overview_convention.htm. Accessed 21 Jul 2018

UNESCO/MaB (2017) A new roadmap for the man and the biosphere (MAB) Programme and its World Network of Biosphere Reserves.-MaB Strategy (2015-2025), Lima Action Plan (2016-2025), Lima Declaration. UNESCO Paris. http://unesdoc.unesco.org/images/0024/ 002474/247418E.pdf.. Accessed Aug 2018

ZRC SAZU (2014) Environmental planning model for cultural heritage sites in southeastern Europe. CHERPLAN Report No. D6.2. Scientific Research Center of the Slovenian Academy of Science and Arts (Slovenia). http://www.cherplan.eu/deliverables/documents. Accessed 24 Apr 2017

Open Access This chapter is licensed under the terms of the Creative Commons Attribution 4.0 International License (http://creativecommons.org/licenses/by/4.0/), which permits use, sharing, adaptation, distribution and reproduction in any medium or format, as long as you give appropriate credit to the original author(s) and the source, provide a link to the Creative Commons licence and indicate if changes were made.

The images or other third party material in this chapter are included in the chapter's Creative Commons licence, unless indicated otherwise in a credit line to the material. If material is not included in the chapter's Creative Commons licence and your intended use is not permitted by statutory regulation or exceeds the permitted use, you will need to obtain permission directly from the copyright holder. 